\title{
Introduction
}

\section{Citizenship as a Rhetorical Practice}

Kock, Christian Erik J; Villadsen, Lisa Storm

Published in:

Rhetorical Citizenship and Public Deliberation

Publication date:

2012

Document version

Early version, also known as pre-print

Citation for published version (APA):

Kock, C. E. J., \& Villadsen, L. S. (2012). Introduction: Citizenship as a Rhetorical Practice. In C. Kock, \& L.

Villadsen (Eds.), Rhetorical Citizenship and Public Deliberation (pp. 1-10). Pennsylvania State University Press.

Rhetoric and Democratic Deliberation Vol. 3 


\section{Christian Kock and Lisa Storm Villadsen \\ Introduction: Citizenship as a Rhetorical Practice}

"[t]he assemblies ... will deliberate better when all are deliberating jointly, the common people when with the notables and these when with the masses" (Aristotle, Politics 1298b).

"There is a relationship between attentiveness and care, and to care about democracy is to care whether and how citizens speak" (Hariman 2007, 224).

Citizenship has long been a keyword among educators, philosophers, and political theorists. Using the phrase 'rhetorical citizenship' as a unifying perspective, this book aims to develop an understanding of citizenship as a discursive phenomenon in the sense that important civic functions take place in deliberation among citizens and that discourse is not prefatory to real action but in many ways constitutive of civic engagement. The book pursues this aim by bringing together, in a crossdisciplinary effort, contributions by scholars in fields that rarely intersect.

\section{Liberal vs. republican notions of citizenship}

For the most part, discussions as well as implementations of citizenship have focused on those aspects of it that are central to the 'liberal' tradition of social thought - that is, questions of the freedoms and rights of citizens and groups.

This present collection gives voice to a 'republican' conception in the thinking about citizenship. Seeing participation and debate as central to being a citizen, this tradition looks back to the Greek city- 
states and republican Rome. Citizenship, in this sense of the word, is basically, we argue, rhetorical citizenship. Rhetoric, on this view, is at the core of being a citizen.

\section{'Deliberative Democracy'}

Our concern to see citizenship as rhetorical parallels the trend in modern political theory which sees the essence of democracy in the idea of deliberation. If we are to connect these two ideas, citizenship and deliberation, and reflect constructively on their meaning in present-day democracy, then we should not only talk about rights and freedoms, but also about rhetoric.

Aristotle was the first major thinker to connect these notions; deliberation (boule, bouleusis) is central both to his political, ethical, and rhetorical thought. To deliberate, he says, is to reflect on the pros and cons of "things that are in our control and are attainable by action" (Nicomachean Ethics, 1112b). His ethics focuses on deliberation followed by choice (proairesis) in the individual. Rhetoric is deliberation in public about communal choice: its function "is to deal with things about which we deliberate, but for which we have no systematic rules" (Rhetoric, 1357a). This also makes clear why he saw rhetoric "as an offshoot of Dialectic and of the science of Ethics, which may be reasonably called Politics" (1356a). Politics is the highest art since its goal is to strive for the good life for all citizens; but that can only be done by wise choices, and these depend on public deliberation, i.e., on rhetoric.

A similar rationale informed the conference "Rhetorical Citizenship and Public Deliberation" held in Copenhagen in October 2008, where the chapters in this book were originally presented. Reflection on citizenship in a democracy must concern itself with public deliberation, and hence with rhetoric.

\section{Is Deliberation Possible?}


It is sometimes assumed that in modern states 'direct' democracy as known from ancient city-states is unworkable, so citizens cannot really be deliberators. If citizenship, as in the liberal tradition, is understood mainly as the rights and freedoms accorded to citizens, individuals tend to be seen as participants in the political process only in so far as they elect representatives who govern the land. Also, the 'liberal' view of democracy tends to see citizens as constituencies (or 'segments') with given and stable preferences. Democracy, on such a view, is like a marketplace, and citizens are like consumers whose needs, interests, and preferences follow from socio-economic parameters. Elected representatives, in turn, are like channels relaying the preferences of their constituencies into legislation and governance, rather than deliberators arguing about what is best for the polity.

One corollary of this is that the assumed function of deliberation shrinks. A minor role is assigned to persuasion which moves individuals from supporting a policy to opposing it, or conversely. Citizens vote, representatives bargain and negotiate. A further, and stronger, corollary is that people are primarily concerned about maximal preference fulfillment. Widespread views posit that people's preferences may be exhaustively expressed in terms of their perceived personal (or even personal economic) utility, regardless of what might be best for the polity. Modern political communication, with its reliance on marketing techniques that target segments selectively, appealing to their assumed group preferences, bears witness to this.

The fragmentation of the citizenry implied by these views and trends points to an important reason to reinvigorate the republican-rhetorical aspect of citizenship. If politics is about the best interest of the polity, rather than merely the aggregated interests of mutually insulated segments, then public deliberation is called for. That need is accentuated by another current megatrend: the multicultural development. As diverse cultures increasingly seek access and acceptance in modern democracies, it is natural that concerns over collective identity, social cohesion, and the difficulties of inter-segmental 
communication (if any) come to the fore. Much thinking on citizenship in social philosophy and democratic theory has addressed issues connected with multiculturalism, and that goes for thinking within the liberal-democratic tradition too, but still it remains fair to say that this thinking, for all its differences, has dealt primarily with freedoms, rights, and duties (or negations of them) - not with the discursive aspects of democracy in multicultural societies.

\section{Deliberation as Speaking and Listening}

If citizenship is understood as essentially deliberative, it necessarily implies two complementary discursive manifestations: deliberating citizens, and their elected representatives, must not only speak, but also listen. Democracy becomes less like a marketplace, more like a forum. Deliberation means 'weighing'; and that, when applied to public issues, implies holding together all reasons and considerations relevant to the issue - not only those of one's own that speak for a given policy, but also others that may speak against it, and which one has not yet considered.

The need to listen as well as to speak is further accentuated in complex societies as our own where new phenomena (such as new digital services), new opportunities, and new threats seem to multiply exponentially. Globalization and digital media are two major factors creating increased attention to national and global citizenship, and to the opportunities and the need to communicate across space and other barriers. Much hope has been invested in the supposed empowering potential of the Internet as a means for anybody to have a say; as to whether and how that promise will be made good, assessments differ, and all the data are not yet in.

A primarily rights-based, liberal conception of citizenship becomes less adequate in postmodern societies characterized by self-reflexivity and globalization, just as the view of the individual as having a fixed identity with fixed preferences loses plausibility. As many social theorists in our time have 
made clear, the individual's identity has become a life-long project of learning, adaptation, and transformation. The idea, easily enhanced by classical conceptions of liberal democracy, that we are all more or less what we are, each of us with interests and preferences that primarily reflect our sociological habitus, becomes less credible. The more diverse a society becomes, the more pressing is the need for public reflection on what is best for the society as such and not just for its segments - in other words, the need for deliberation; for rhetoric.

An immediate implication is that elected representatives must be deliberators rather than just negotiators. But it also becomes increasingly urgent for citizens themselves to take part in public exchange that invokes not only segment interests but also the common good. As a leading political theorist and proponent of deliberative democracy, John Dryzek, has recently argued:

A deliberative democracy cannot easily be sought in a single forum. Instead, it should be sought in the contributions of multiple sites - and representations across these sites. Rhetoric can enable effective communication between differently situated actors, and can both establish and maintain deliberative systems. $(2010,320)$

But rhetorical citizenship has more to it than deliberative exchange among representatives and citizens across multiple sites. In a modern polity it is not only possible but also necessary that citizens deliberate even when they are not public agents in deliberation. They will need not only to attend to the deliberation of their elected or would-be representatives and other public debaters, but also, on that basis, to deliberate tacitly, in their own minds, as well as among themselves, on who has made the best case for what the polity should do - and who accordingly deserves their support, at elections or in between. 
So, for citizens in deliberative democracy, the relevance of rhetoric is at least twofold: to become an active agent in such a democracy, he or she must be a deliberative rhetor; and even citizens placed at the receiving end of public deliberation (newspaper readers, TV viewers, public debate audiences, etc.) must themselves engage in 'inner' deliberation. Rhetorical citizenship is concerned with citizens' output as well as their intake of public deliberation. Careful monitoring of the public deliberation they hear or see is an important part of their deliberative engagement. In Dryzek's words:

Representative democracy and the deliberative system make rhetoric necessary. But its well-known hazards remain. So we still need some way to sort defensible uses of rhetoric from undesirable uses.

On this view, there is a need for rhetoric in a deliberative democracy as well as for critical observation, description, and evaluation of the rhetoric that does occur - not just discourse by public officials or candidates, but also other forms of discursive participation in public debate, partly to get a broader view of what is out there, but also to understand more fully the empowering and emancipatory aspects of rhetoric in society.

\section{Rhetoricians Meet Deliberative Democrats}

As rhetorical scholar Robert Hariman noted, "understanding, appreciating, and improving democratic participation is impeded by both the rationality standards of deliberative democracy theorists and classical rhetoric's ideal of eloquence" $(2007,222)$. This is a call for scholarly approaches that better account for, and can offer suggestions, to actual civic discourse. Discourse cannot be studied merely as a theoretical or idealized notion. Public discourse is concrete, manifest, omnipresent, visible, 
and accessible for all; anyone can relate to it, and it is the conduit of numerous societal functions and dynamisms. We offer the concept of rhetorical citizenship as a way of conceptualizing the discursive, processual, participatory aspects of civic life. As Hauser puts it: “A public's essential characteristic is its shared activity of exchanging opinion. Put differently, publics do not exist as entities but as processes; their collective reasoning is not defined by abstract reflection but by practical judgment; their awareness of issues is not philosophical but eventful" (64; emphasis in original).

Several rhetoricians have engaged deliberative democracy with appreciation of its focus on the actual discursive aspects of democratic systems as well as its concern with strengthening public participation in civic life. Multiple varieties of public discourse may be seen as instantiations of citizenship. Hauser's seminal work on 'vernacular rhetoric' helped reorient rhetorical scholars' concern with political rhetoric to include informal and everyday instances of civic interaction. Robert Asen and Dan Brouwer suggested the metaphor of 'modality' as a vehicle for studying and being public (2010). Their affirmation of plurality in public activity and in scholarship is one that we share. This volume thus brings together multiple disciplinary traditions of studying public discourse, as well as a variety of case studies; together they argue that our individual contributions to civic life can take many forms as we are called on in a range of different qualities, e.g., as voters, members of interest groups, employees or students with certain affiliations, or even as family to individuals who rely on public care facilities. In his "discourse theory of citizenship", Asen similarly encourages us to view citizenship as a "mode of public engagement" and thereby recognize "fluid, multimodal, and quotidian enactments of citizenship in a multiple public sphere" (191), seeing democracy more as a "guiding spirit that informs human interaction" than "a set of institutions or specific acts" (196). A rhetorically based understanding of public debate can risk engaging difference without that risk leading to reduced commitment; rather, "a commitment to engaging others privileges norms of inclusion and fairness" (201). 
A rhetorical focus has a special regard for individual actors in the public arena, not just the eloquent politician or NGO representative, but also the person watching a pre-election debate on $\mathrm{TV}$, chipping in with a point of view on a blog on civic issues, collecting signatures from passersby on a windy street to stop municipal budget cuts, or deciding to join a local interest group.

Focusing on how citizens actually deliberate allows us to consider both macro and micro practices, but always with an eye to the significance for the individuals involved. For example, what forms of participation does a particular discursive phenomenon encourage - and by whom? How are speaking positions allotted and organized? What discursive norms inform a particular public forum? What possibilities are there for 'ordinary' citizens to engage in public discourse? How do some people come to see themselves as legitimate voices in public debate? How does one assess arguments presented on public issues?

While rhetorical citizenship as a concept has no ideological bent, it is clearly normative in its attention to notions of empowerment, inclusivity, and discourse ethics. Among several scholars who study norms of engagement and expectations to public deliberation is Robert Ivie, who identifies as a key challenge "how to communicate politically without an exclusionary aim for consensus and unity or a reduction of difference to total otherness" $(2004,278)$. In his call for "rowdy" deliberation, he seeks a rhetorical conception of deliberation that promotes democratic practice in the here and now rather than postponing it into a hypothetical future, disciplined by the illusion of rational consensus (278). He applauds Iris Marion Young's argument that an adequate understanding of political deliberation must encompass rhetoric as a necessary and positive attribute, but he extends the thought and argues that democratic deliberation is best understood as primarily rhetorical. Such an understanding is tantamount to accepting political discussion as essentially agonistic and robust enough to accommodate a measure of disagreement as sound and genuinely democratic. 


\section{Citizenship and Rhetorical Agency}

Many of these concerns are central to a second theoretical strand informing our thinking on rhetorical citizenship: the concept of rhetorical agency, which has gained attention by highlighting issues of voice, power, and rights. In rhetorical studies it has shown a way around an unproductive chasm with traditionalist, rhetor-centered, instrumental notions of rhetoric on the one side and poststructuralist, constructivist conceptions on the other. Cheryl Geisler observes that the concept spans instrumental aspects of rhetoric as well as social, institutional, political, and cultural factors conditioning a speaker's access to speaking and being heard (12-13). Focusing on the complexity of rhetorical events, it invites us to consider contextual factors influencing the particular event, and underscoring the structural aspects and the fluid nature of rhetorical force: for example, a person enjoying institutional authority in one setting may have difficulty gaining a hearing in another, and conversely.

\section{A Cross-disciplinary Effort}

For years, many scholarly disciplines have engaged the idea of citizenship, but too often their thinking has moved in relatively closed circuits. Scholars need to pool their insights and communicate, as well as learn, across disciplinary boundaries. This book aims to show that no one scholarly angle is sufficient, yet all are necessary. Its interdisciplinarity - to say nothing of the broad range of nationalities it represents - is one feature setting this volume apart from most work on citizenship so far, including the rhetorical studies we have alluded to. The careful study of authentic public communication as it actually takes place is traditionally one of rhetoricians' strong suits; here they have something to offer to scholars from other disciplines that also study the workings of democracy. 
Political science and philosophy have not traditionally engaged in precisely this kind of studies, but have much to offer by way of conceptual analysis as well as empirical research.

We believe the concept of rhetorical citizenship embraces scholarship from a range of disciplines, including communication studies, discourse analysis, political philosophy, and also fields outside of the humanities such as political science and sociology. The concept may serve as an umbrella term covering a range of scholarly approaches to communication in the public, and particularly the political, sphere. Finally, the concept is well fit to mediate between theory and critical inquiry.

This volume consists of chapters that address in one aspect or another a general concern with the makeup and enhancement of public deliberation. It adopts a rhetorical lens, even as it brings together authors from multiple disciplines. This rhetorical perspective emphasizes a diversity of actual deliberative practices, holding its conceptualizations accountable to, as many authors put it, a vernacular practice that considers how everyday people participate and practice citizenship, and how everyday practices might be enhanced.

The volume presents work on the possibilities for, obstacles to, and potentialities in public deliberation, as well as critical case studies of such engagement. The chapters in this book have been organized in three broadly defined sections.

Section I, "Tracing Rhetorical Citizenship as Concept and Practice," considers historical roots of deliberation as a concept and a practice. Three chapters suggest that those wishing to give more attention to the discursive aspects of democracy might look back for insight and precedent - not just to the immediate past, where notions of deliberative democracy sprang up in many quarters, but all the way back to those original 'rhetorical citizens,' the Greek sophists, as well to practical attempts in the not-so-distant past to implement democracy as a discursive phenomenon. 
Section II, "Public Deliberation as Rhetorical Practice" comprises twelve chapters addressing criteria of various kinds that either do or arguably could influence in positive ways the manner in which public deliberation is currently practiced. The first papers in the section take a theoretical, even a philosophical approach; the later ones look at specific contemporary practices and instances of political and other public talk, representing several countries, and instancing physical as well as mediated and virtual subsections of the public sphere.

Section III, "Towards Better Deliberative Practices," looks forward. Ranging from the specific genre of presidential primary debates to a general consideration of social and ethical controversies, it offers three chapters considering how public deliberative debates might become more constructive without prescribing consensus.

This might be fitting note on which the end this introduction. We believe that, unlike many earlier exponents of deliberative democracy, believers in rhetorical citizenship do not hold up the achievement of full agreement or the elimination of conflict as guiding ends. Harmony is not unison. Nor are the chapters in this collection.

\section{References}

Aristotle. Rhetoric. Aristotle in 23 Volumes, Vol. 22, translated by J. H. Freese. Cambridge and London: Harvard University Press; William Heinemann Ltd. 1926.

Aristotle. Nicomachean Ethics. Aristotle in 23 Volumes, Vol. 19, translated by H. Rackham. Cambridge, MA: Harvard University Press; London: William Heinemann Ltd. 1934. 
Aristotle. Politics. Aristotle in 23 Volumes, Vol. 21, translated by H. Rackham. Cambridge, MA: Harvard University Press; London: William Heinemann Ltd. 1944.

Asen, Robert. “A Discourse Theory of Citizenship.” Quarterly Journal of Speech 90 (2004): 189211.

Brouwer, Daniel C., and Robert Asen. "Introduction: Public Modalities, or the Metaphors We Theorize By." Public Modalities: Rhetoric, Culture, Media, and the Shape of Public Life. Daniel C. Brouwer and Robert Asen (eds.) Tuscaloosa: University of Alabama Press 2010: 1-32.

Dryzek, John. "Rhetoric in Democracy: A Systemic Appreciation." Political Theory 38(3) (2010): 319-339.

Hariman, Robert "Amateur Hour: Knowing what to Love in Ordinary Democracy." The Prettier Doll. Rhetoric, Discourse, and Ordinary Democracy. Karen Tracy, James P. McDaniel, and Bruce Gronbeck (eds.) Tuscaloosa: University of Alabama Press, 2007: 218-250.

Hauser, Gerard A. Vernacular Voices. The Rhetoric of Publics and Public Spheres, University of South Carolina Press (1999)

Ivie, Robert L. "Rhetorical Deliberation and Democratic Politics in the Here and Now." Rhetoric \& Public Affairs 5 (2002): 277-285. 